\title{
СИНТЕЗ И ФАРМАКОЛОГИЧЕСКАЯ АКТИВНОСТЬ АДАМАНТИЛСОДЕРЖАЩИХ ИМИДАТОВ
}

\author{
Ю.Л. Зотов' , Д.С. Климов', П.М. Васильев² \\ ${ }^{1}$ Волгоградский государственный технический университет, \\ 400005, Россия, г. Волгоград, пр. им. Ленина, 28, \\ ${ }^{2}$ Волгоградский государственный медицинский университет, \\ 4000066, Россия, г. Волгоград, пл. Павших борцов, 1.
}

DOI: 10.19163/MedChemRussia2021-2021-223

E-mail:ylzotov@mail.ru

Многие азотсодержащие производные адамантана обладают биологической активностью. Некоторые из них выпускаются и применяются как лекарства (ремантадин, мидантан). О биологической активности имидатов известно давно, а проведенные нами исследования показали, что спектр действия таких соединений очень широк.

Нами синтезирована серия адамантан-содержащих имидатовс целью последующего скрининга на различные виды активности:

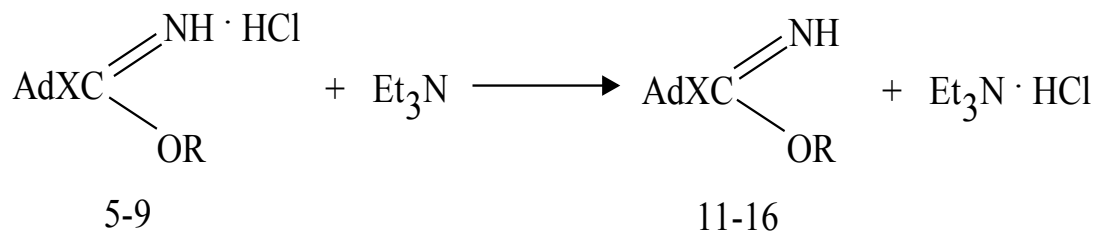

Для всех синтезированныхвеществ был проведен вычислительный прогноз по 15 видам биологической активности. Массив обследованных имидатов составил 28 соединений, различающихся заместителями адамантильной группы.

Результаты компьтерного скрининга свидетельствуют о том, что потенциальными “фармакофорами”, определяющими спектр биологической активности соединений являются адамантильная и иминоэфирная группы. Химическая природа углеводородной эфирной группы, не содержащей адамантан, оказывает незначительное влияние на уровень биологической активности.

В итоге прогнозируется следующие виды медико-биологической активности: антидепрессантная, фунгицидная, антигерпесная, нейролептическая, ноотропная, антипикорновирусная, антисептическая, транквилизирующая, туберкулостатическая. 